\title{
Implementing Official Dollarization
}

\author{
Luis I. Jácome and Ake Lönnberg
}




\title{
IMF Working Paper
}

\author{
Monetary and Capital Markets Department
}

\section{Implementing Official Dollarization}

\author{
Prepared by Luis I. Jácome and Åke Lönnberg ${ }^{1}$ \\ Authorized for distribution by Karl Habermeier
}

April 2010

\begin{abstract}
This Working Paper should not be reported as representing the views of the IMF.

The views expressed in this Working Paper are those of the author and do not necessarily represent those of the IMF or IMF policy. Working Papers describe research in progress by the author and are published to elicit comments and to further debate.
\end{abstract}

This paper identifies key aspects that countries willing to officially dollarize must necessarily address. Based on country experiences, it discusses the critical institutional bases that are necessary to unilaterally introduce a new legal tender, describes the relevant operational issues to smooth the transition toward the use of the new currency, and identifies key structural reforms that are necessary to favor the sustainability over time of this monetary regime. The paper is aimed at providing preliminary guidance to policy makers and practitioners adopting official dollarization. The paper does not take a position on how appropriate this monetary arrangement is. Experiences from adopting dollarization in Ecuador, El Salvador, Kosovo, Montenegro, and Timor-Leste are illustrated briefly.

JEL Classification:

Keywords: Central bank, exchange rate, dollarization.

Authors’ E-Mail addresses: ljacome@,imf.org, alonnberg@,imf.org

\footnotetext{
${ }^{1}$ The authors would like to thank Karl Driessen, Simon Gray, Karl Habermeier, and other colleagues in the Monetary and Capital Markets Department for helpful comments on earlier versions of this paper. We are particularly indebted to Alain Ize for reading, extensively commenting, and discussing the content of the paper. Remaining errors and omissions are the authors' responsibility.
} 


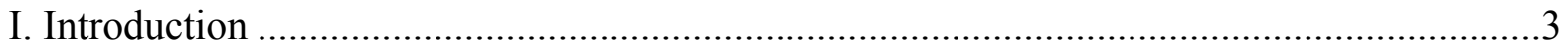

II. Official Dollarization: Where do we Stand? ....................................................................

III. Implementing Unilateral Official Dollarization: Key Issues to Address...........................

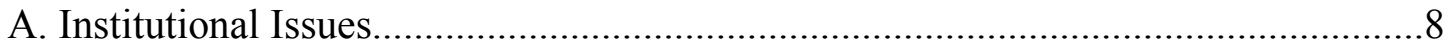

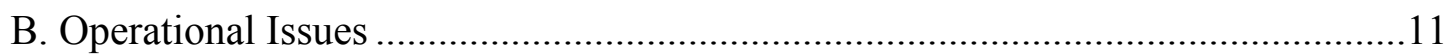

IV. Key Complementary Structural Reforms .......................................................... 17

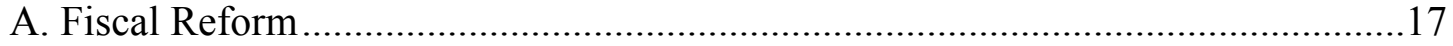

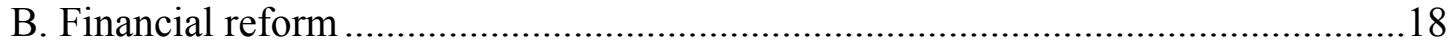

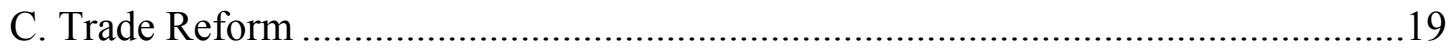

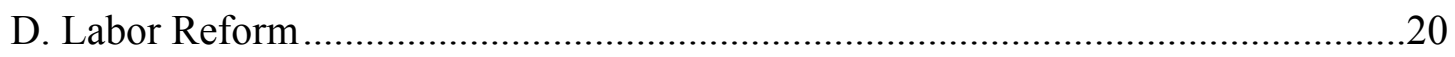

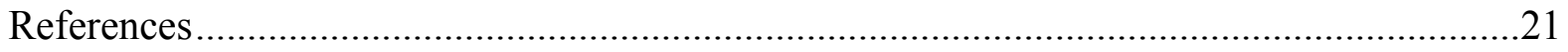

22

Tables

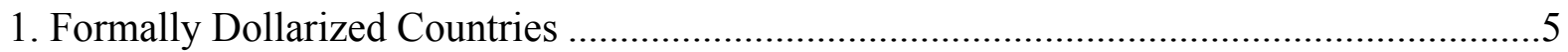

Figures

1. Key Macroeconomic Indicators in Selected Dollarized Countries................................... 7

Appendices

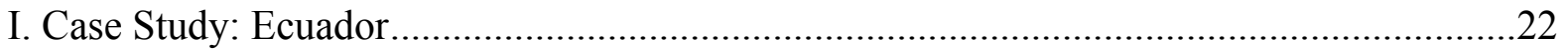

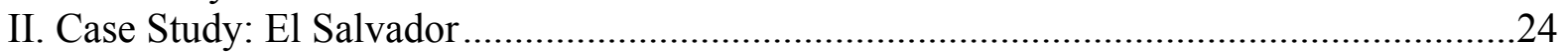

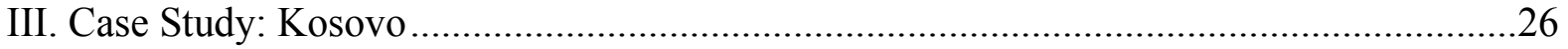

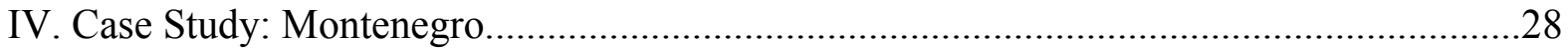

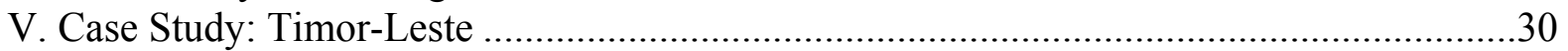




\section{INTRODUCTION}

The purpose of this paper is to identify key institutional and operational aspects that countries willing to officially dollarize must necessarily address. ${ }^{2}$ Based on country experiences, we identify the main decisions that are necessary to unilaterally introduce a new legal tender. The paper is aimed at providing guidance to policy makers and practitioners in this endeavor. Given its operational focus, the paper does not take a position about how appropriate this monetary arrangement is.

Official dollarization has been a topic of interest during the last two decades. Initially, de jure unilateral dollarization had gained popularity between academics and policy makers after Ecuador and El Salvador adopted the U.S. dollar as legal tender. ${ }^{3}$ However, following the demise of the Argentinean currency board in 2002 and its political and economic aftermath, enthusiasm for super-fixed exchange rate regimes, including dollarization, decreased. Today, in the context of the recent world financial instability, a renewed interest has emerged about the benefits of adopting this monetary regime, even as a unilateral decision. Behind this interest is the perception that by not having a domestic currency, countries could have avoided major depreciations, which, in some countries, eventually damaged their financial systems. ${ }^{4}$ In general, the most important rationale for dollarization has been the desire to import a tested monetary policy framework that facilitates preserving price stability and contributes to fostering economic growth. Other than this, post-conflict countries as well as many small open economies that are closely linked to a large country issuing a strong international currency — via trade and capital flows - have always maintained formal dollarization on their radar. This is more often the case for developing countries, less so for developed economies with strong monetary policy credibility.

Official dollarization has elicited some interest, but this has mostly focused on the benefits of adopting this monetary arrangement and has not addressed implementation issues. The literature on dollarization has primarily focused on its pros and cons (see Berg and Borensztein (2000), Panizza and others (2003), and Levy-Yeyati and Sturzenegger (2003)). A few other studies have been produced to answer questions such as when or which countries should dollarize (Eichengreen (2002) and Calvo (2002)). Geographically, studies have mostly looked at Latin America given the vast de facto dollarization in this region (Corbo (2001) and Salvatore (2001)), with little emphasis on country experiences, except for

\footnotetext{
${ }^{2}$ By official dollarization, we mean a country's unilateral decision of adopting a foreign currency as a legal tender. The term dollarization, therefore, also encompasses euroization, that is, the adoption of the euro as a legal tender. In that context, it excludes the formal accession to the euro area by European Union (EU) member states.

${ }^{3}$ The term "legal tender" is here defined as the currency used in a country that, by law, may be offered in payment of a debt and that a creditor legally cannot refuse.

${ }^{4}$ In practice, capital outflows hit all countries alike and, in the case of the dollarized economies, financial systems still received the impact via lower external financing.
} 
Panama (Moreno-Villalaz (1999) and Goldfajn and Olivares (2001)). Only Gruben and others (2003) address operational aspects of dollarization.

The rest of the paper focuses primarily on how to implement unilateral dollarization. ${ }^{5}$ Section II provides a summary view of official dollarization in the world map; section III identifies the main institutional and operational issues to be addressed when a country dollarizes; section IV singles out key structural reforms that should be approved in order to strengthen credibility and sustainability of dollarization. Experiences from adopting dollarization in Ecuador, El Salvador, Kosovo, Montenegro, and Timor-Leste are illustrated briefly in the appendix to this paper.

\section{OfFicial Dollarization: WHERE Do We StAND?}

Adopting a foreign currency as a legal tender entails costs and benefits. Conventional wisdom typically identifies the costs associated with official dollarization as: (i) loss of seigniorage; (ii) limited or no ability to provide lender-of-last-resort (LOLR) assistance to troubled banks; (iii) lack of exchange rate to be used as a shock absorber; and (iv) inability to reduce the value of financial commitments denominated in domestic currency via a large exchange rate depreciation or through fueling inflation. In turn, benefits of officially adopting dollarization are: (i) convergence of domestic inflation towards world inflation; (ii) elimination of currency risk, which reduces domestic interest rates; (iii) better environment for investment as a result of stable inflation and lower interest rates; and (iv) absence of the so-called "original sin," which help to reduce the country risk as currency mismatches in the country's balance sheet disappear. ${ }^{6}$

Against this background, as of end-2008, eleven countries have unilaterally dollarized worldwide (Table 1). Three of these countries are emerging markets, one is a high income country, and the rest are developing nations with very small economies - some of them considered micro states. ${ }^{7}$ Seven countries substituted their domestic currency for the U.S. dollar and three countries dollarized in the current decade. Yet, only two countries, Ecuador and El Salvador, went through the complex endeavor of replacing their established national currencies with the U.S. dollar as legal tender. Kosovo, Montenegro, and TimorLeste shifted from one to another foreign currency prior to becoming independent states.

\footnotetext{
${ }^{5}$ Issues not covered in this paper also include implementing bilateral dollarization, acceding to the European Union, or how to introduce a monetary union.

${ }^{6}$ The "original sin" refers to a situation in which countries are unable to issue debt in their own currency and, hence, obtain financing by issuing debt denominated in a major international currency. As a result, countries become vulnerable to large exchange rate depreciations as they may increase considerably government expenditures, casting doubts about the countries capacity to pay back the debt.

${ }^{7}$ These nations typically have small and not necessarily wealthy populations, which cannot easily reach economic "critical mass." In addition, they are closely integrated with a big neighboring country. Since the fixed cost of issuing own currency is high, these countries have rather decided to use an existing currency.
} 
Table 1. Formally Dollarized Countries (Excluding participants in currency unions; based on the IMF's classification in the AREAER ${ }^{1 /}$ )

\begin{tabular}{lccccc}
\hline Country & $\begin{array}{c}\text { Year } \\
\text { adopted }\end{array}$ & $\begin{array}{c}\text { Currency } \\
\text { adopted }\end{array}$ & $\begin{array}{c}\text { Issue of } \\
\text { national coins }\end{array}$ & $\begin{array}{c}\text { GDP (in billion } \\
\text { (of U.S. dollar) }\end{array}$ & $\begin{array}{c}\text { Previous own } \\
\text { national currency }\end{array}$ \\
\hline Ecuador & 2000 & U.S. dollar & Yes & 45.79 & Yes \\
El Salvador & 2001 & U.S. dollar & No & 20.37 & Yes \\
Kiribati $^{4 /}$ & 1979 & Australian dollar & No & 0.067 & No $^{5 /}$ \\
Kosovo $^{5 /}$ & 1999 & euro $^{6 /}$ & No & 4.688 & No \\
Marshall Islands $^{4 /}$ & 1986 & U.S. dollar & No & 0.163 & No \\
Micronesia $^{4 /}$ & 1986 & U.S. dollar & No & 0.232 & No \\
Montenegro $^{4 /}$ & $1999^{5 /}$ & euro ${ }^{6 /}$ & No & 3.49 & No \\
Palau & 1994 & U.S. dollar & No & 0.164 & No \\
Panama & 1904 & U.S. dollar & Special case $^{7 /}$ & 19.74 & Special case \\
San Marino & 1999 & Euro & Special case $^{8 /}$ & 1.7 & No \\
Timor-Leste & 2000 & U.S. dollar & Yes & 0.46 & No \\
\hline
\end{tabular}

1/ Annual Report on Exchange Arrangements and Exchange Restrictions (2009), except for Kosovo which is not included. Also not included are three non-IMF member states (Andorra, Monaco, and the Vatican), which are using the euro after a special agreement with the EU authorities although they are not members of the EU.

2/ Excludes the issuance of coins for primarily numismatic purposes.

3/ As of 2007.

4/ The year of adoption corresponds to the countries' independence date.

5/ Prior to 1979, Kiribati issued national coins, some of which are still in circulation.

6/ The Deutsche mark (DM) was introduced as parallel legal tender to the Yugoslav dinar.

7/ Panama maintains the balboa as the national currency, but only balboa coins circulate.

8/ San Marino uses the euro on the basis of a formal arrangement concluded in 2000 with the European Community, through a monetary agreement with Italy (on behalf of the European Community). This arrangement allows the use of the euro as the official currency, and the minting of a specific amount of coins for circulation, collection, and commemorative purposes.

Source: Annual Report on Exchange Arrangements and Exchange Restrictions, International Monetary Fund.

During 2009, Zimbabwe transited to a unique form of unilateral an officially dollarized economy. In an environment of hyperinflation - after years of quasi-fiscal operations and central bank monetization of government deficits - the government officially authorized the use of any traded foreign currency as legal tender without formally abolishing the Zimbabwe dollar as legal tender. ${ }^{8}$ The most prominent currency used during 2009 was the U.S. dollar while the South African rand was, to a considerable extent, used for small cash transactions. Neighboring countries' currencies are also used in some regions.

\footnotetext{
${ }^{8}$ Zimbabwe reached a hyperinflation in February 2007. In mid-November 2008, the monthly inflation rate was estimated at 79,600,000,000 percent—equivalent to a daily rate of 98 percent—unmatched since the hyperinflation in Hungary in 1946. A number of re-denominations of the national currency in 2006-09 failed to restore confidence in the Zimbabwe dollar. As a result, this currency gradually went out of circulation during the second half of 2008, as people started to demand foreign currencies for payments.
} 
A snapshot of key macroeconomic indicators shows that dollarized economies have, in general, performed well vis-à-vis other groups of countries, classified by exchange rate regimes. ${ }^{9}$ The most remarkable outcome is that, during 2004-2009, inflation converged to and remained close to world inflation in the dollarized countries-including in Ecuador, where inflation had reached 100 percent year-on-year in 2000. Merging these countries with others featuring hard peg regimes, shows that inflation was on average lower and volatility larger because of the high pass through to domestic inflation originated on the 2007-2008 supply shock (Figure 1). ${ }^{10}$ In turn, economic growth in hard-peg countries was less dynamic and more volatile than in the rest of the developing and emerging market countries. Among the dollarized countries, aggregate figures hide an uneven performance on a country basis, with Panama ranking at the top ( 7.6 percent) and El Salvador at the bottom (2.3 percent) during 2004-2009. The other remarkable outcome is that dollarized countries seem to have maintained their fiscal position in check and a stronger fiscal stance than the rest of the developing and emerging market countries.

Focusing exclusively on the officially dollarized countries, country risks indicators have improved, except in Ecuador. The EMBI spread for El Salvador and Panama was lower or close to the composite EMBI spread, reflecting their strong fiscal position, their capacity to pay back their debts, and the absence of currency risk. Interest rates margins over similar U.S. rates also followed the same trend. Not surprisingly, both indicators rose in the wake of the recent financial crisis in El Salvador and Panama as a result of capital outflows-like in other emerging markets - and fears of possible banking crises, given the large presence of U.S. and European banks in those economies. The maintenance of an elevated country risk and higher interest rates in Ecuador reflect idiosyncratic factors of political economy nature, which that ultimately led to a debt default in 2008.

\footnotetext{
${ }^{9}$ We picked 2004 as the first year of the comparative period in order to capture the steady state information in the dollarized economies.

${ }^{10}$ The classification of countries is based on the 2008 IMF's Annual Report on Exchange Arrangements and Exchange Restrictions. The sample of dollarized countries comprises the four largest dollarized economies, namely Ecuador, El Salvador, Panama, and Montenegro. The hard-peg countries comprise a total of 30 countries: the former group, the currency board countries (Bosnia \& Herzegovina, Brunei Darussalam, Bulgaria, Djibouti, Estonia, and Lithuania), plus the countries belonging to the East Caribbean and the two African currency unions. The inflation targeting group includes Brazil, Chile, Colombia, Ghana, Guatemala, Hungary, Indonesia, Mexico, Peru, Philippines, Poland, Romania, Serbia, South Africa, Thailand, and Turkey. In addition, excluding the IMF's World Economic Outlook list of 32 advanced countries, the soft-peg countries comprise 63 countries, whereas 39 countries are classified as non-inflation targeting emerging and developing countries featuring flexible exchange rate regimes.
} 
Figure 1. Key Macroeconomic Indicators in Groups of Countries

Inflation

(Annual rate)

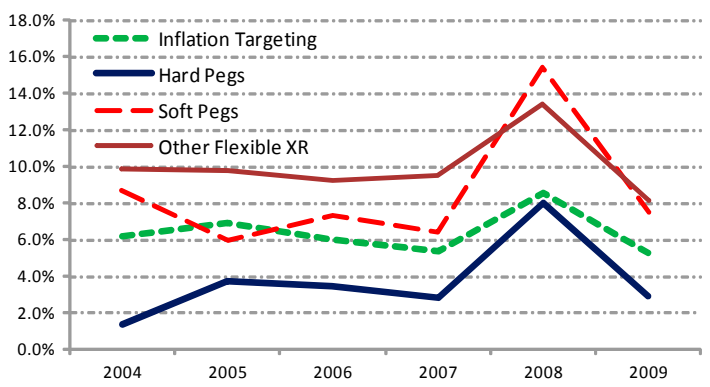

Volatility of Inflation

(Standard deviation)

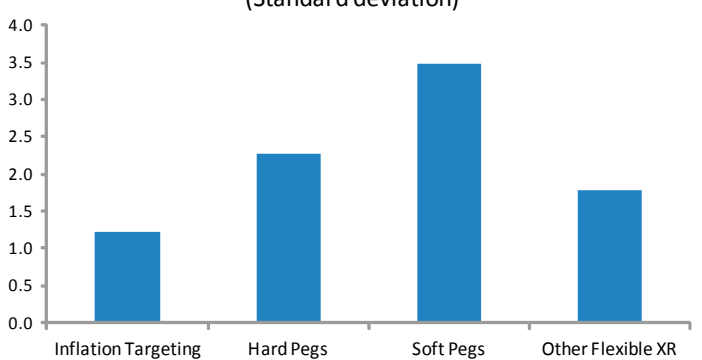

Fiscal Balance

(As a \% of GDP)

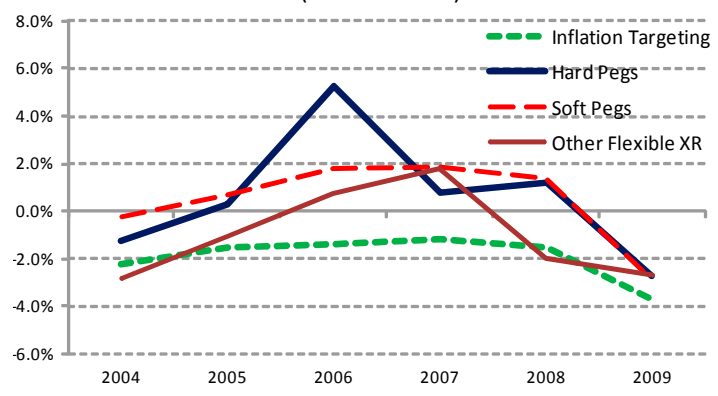

EMBI Spread

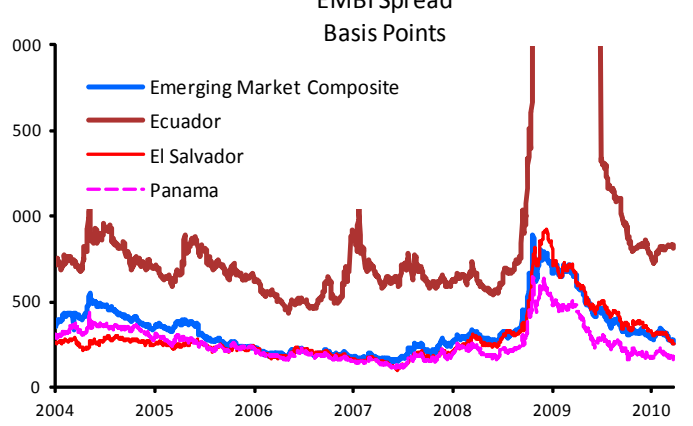

Real GDP

(Rate of growth)

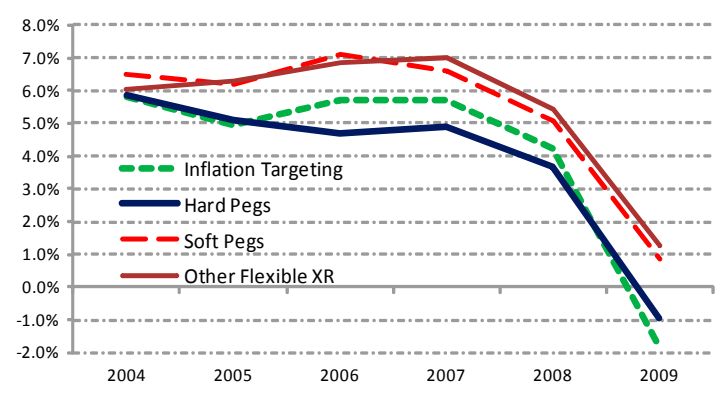

Volatility of Growth

(Standard devation)

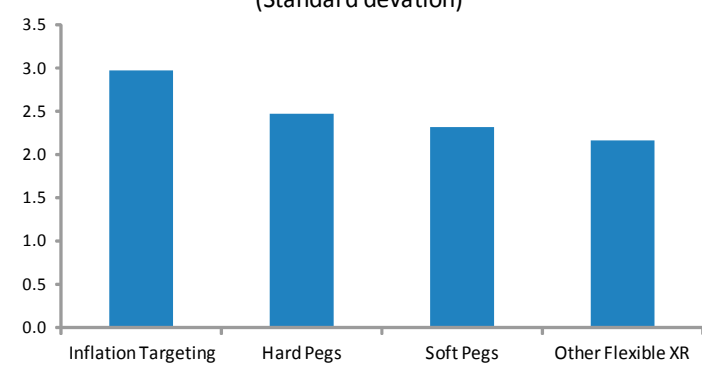

Current Account Balance (As a \% of GDP)

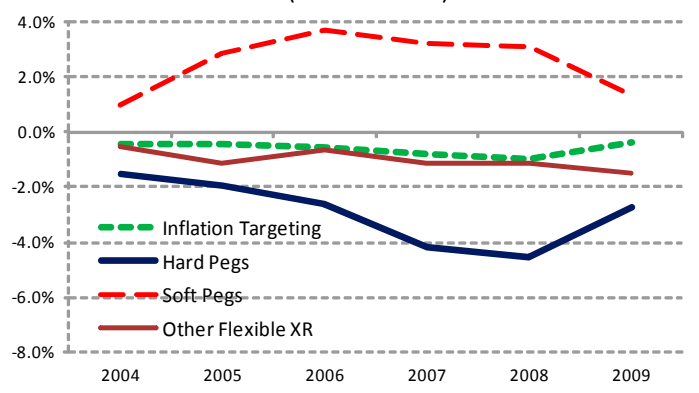

Interest rate margin over US rate In percentages

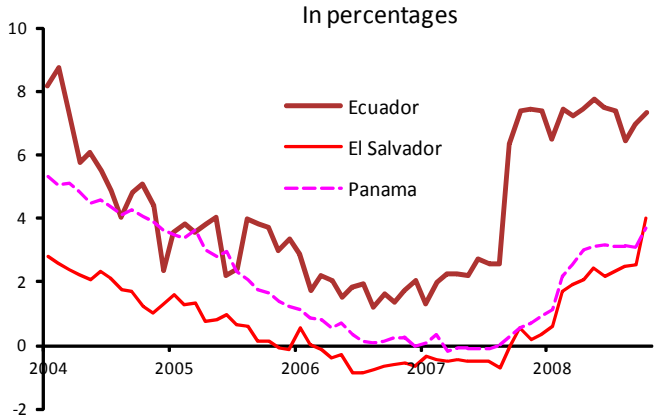

Source: IMF International Financial Statistics, IMF World Economic Outlook, and IMF Annual Report on Exchange Arrangements and Exchange Restrictions. 


\section{IMPLEMENTING UNILATERAL OFFICIAL DOLLARIZATION: KEY ISSUES TO ADDRESS}

A first question to answer is whether specific pre-conditions should exist before adopting de jure dollarization. There are two competing views in this regard; one that believes that having pre-conditions in place before introducing a foreign currency as legal tender will yield more benefits, and the other that claims that dollarization actually puts pressure to immediately adopt similar policies (see Eichengreen (2002)). These pre-conditions, at the minimum, refer to having: (i) a robust financial system and strong financial supervision in order to minimize the likelihood of banking crises in an environment of no- or at most limited-lender of last resort (LOLR) facilities; (ii) solid public finances that give sufficient assurances to market participants about the sustainability of fiscal policy; and (iii) flexible labor markets to facilitate macroeconomic adjustment in response to external shocks. While the circumstances in which Ecuador dollarized suggest that it is not entirely critical to have these pre-conditions in place, having them in place or in a well-advanced stage might increase the chances of achieving a smooth transition and, more importantly, reducing downside risks, which may induce an upward bias in country-risk indicators and domestic interest rates.

Adopting official dollarization entails taking decisions on a vast array of institutional and operational aspects and, hence, there is no single list of issues that all dollarizing countries should address. Most countries have specific structural features; more important, dollarization is typically adopted under diverse circumstances. For instance, while Ecuador dollarized in the midst of a systemic financial crisis with high inflation and under a flexible exchange rate regime, El Salvador did it in an environment of macroeconomic stability and fixed exchange rate. As a result, the rate at which the domestic currency was converted to the U.S. dollar was an issue in Ecuador and not in El Salvador. Similarly, while choosing the new legal tender was not an issue in these two countries, it was a major topic of discussion in the case of Zimbabwe in early 2009.

Yet, there are a number of issues which invariably need to be addressed. These involve institutional matters to define the building blocks of the new monetary arrangement and also operational aspects aimed at securing a smooth transition and the proper functioning of the new monetary regime.

\section{A. Institutional Issues}

Official dollarization demands strong political support. Countries should carefully weigh the costs and benefits of adopting a foreign currency as a legal tender. Once the decision of officially dollarizing is adopted, enacting a clear legal framework is critical, which ideally should be endorsed by the society at large. While large groups in the country may be unwilling to abandon the national currency — many times because of national pride — such endorsement is easier to garner if the country is going through a period of very high inflation. Ecuador and Zimbabwe are cases in point as inflation discouraged using the domestic currency as store of value and, hence, their economies were already de facto highly dollarized. 
Dollarization requires the approval of legislation defining the legal basis of the new monetary arrangement. A new law should be approved by parliament involving changes to the central bank law and to other pieces of legislation, sometimes including the constitution. Other financial sector legislation may also be amended to reflect the changing circumstances, including regulations on accounting or the relevant legislation that allows claims and obligations originally made in the national currency to be converted into the new currency. Also, the regulations governing the operations of national payment systems may need to be evaluated and typically revised.

The new legislation should define an alternative role to the central bank. This implies assigning the central bank a different objective and changing its functions and responsibilities accordingly. While having a central bank is not strictly necessary under formal dollarization, in practice central banks have continued existing in the dollarized countries. Among the largest dollarized countries, Panama has no central bank. Ecuador, El Salvador, and Montenegro have preserved a central bank with no commercial bank responsibilities. Kosovo and Timor-Leste have central banking authorities created after independence, which prominently function as financial sector supervisors. De facto, the new primary objective of central banks in officially dollarized economies typically should be to foster and maintain a stable financial system. Among the various tasks and functions often assigned to the central banks are to conduct financial surveillance and issue prudential and supervisory regulations, handle cash currency (banknotes and coins) ${ }^{11}$ manage international reserves, provide a centralized clearing function for the payment system, serve as fiscal and financial agent of the state, undertake macroeconomic studies, and advise governments on macroeconomic topics. Other typical central bank responsibilities should be prohibited, most notably, printing new currency notes (but not necessarily minting national coins) as well as conducting interest rate policy, while the ability of serving as LOLR is drastically curtailed. ${ }^{12}$

The central bank should be reorganized in line with its new mandate and responsibilities assigned. Its governance arrangement should reflect the new role of the central bank. For instance, if the new mandate of the dollarized central bank is primarily to preserve financial system stability and oversight the payments system, board members should be required to have the relevant expertise, and the board structure, functions, and operational arrangements should be designed accordingly. Also, because seigniorage is eliminated, central bank financing is restricted and, hence, an alternative income model — dependent partially or fully on the government budget - should be developed. If the central bank mandate is primarily to preserve financial stability, financial institutions' contributions should also be an important part of the central bank revenue sources. Provided the central bank does not issue any

\footnotetext{
${ }^{11}$ For historical reasons, the ministry of finance is, in a number of countries, the formal issuer of coins rather than the central bank. In some such cases, limits may exist on the issuance of coins by the central bank as it may be seen as central bank financing of the state budget.

${ }^{12}$ Nonetheless, the Central Bank of Ecuador influences commercial bank interest rates by defining administratively a cap on lending rates. It also regulates fees and commissions charged by commercial banks.
} 
security or bond, it does not require maintaining a specific level of capital. However, because central banks should remain autonomous to exercise its responsibilities aside from short-run political considerations, legislation should establish that the government underwrites central bank liabilities.

Although recent experiences show that countries that unilaterally dollarized typically did not encounter legal constraints from the currency issuing country, some adverse reaction may take place, in particular, when it comes to euroization. Since adopting the euro is the final step in a staged process of convergence and policy coordination, the EU authorities - and not least the Ecofin Council and the European Central Bank (ECB) - are far less complacent with unilateral dollarization using the euro given that member countries should follow the road map in place for adopting the euro as legal tender. ${ }^{13}$ For countries that cannot or will not join the EU, this may not be a major issue. By early-2010, this matter is especially topical for Montenegro, where membership discussions with the EU are underway, and for Kosovo, which plans to apply for membership. So far, there have been no cases of acceding countries in the EU which were unilaterally euroized at their time of accession. It is, therefore, a considerable uncertainty about the way these cases will be dealt with, and that this will likely be determined at the time of accession.

In general, approaching the authorities from the country that issues the new legal tender is warranted to explore areas of cooperation. This cooperation may involve a wide range of issues, from seeking a comprehensive agreement for a formal monetary association at one extreme - with the aim of obtaining a share on the seigniorage generated in the issuing country - to a simple cooperation agreement to facilitate the availability of banknotes (and maybe coins). ${ }^{14}$ In the latter scenario, countries might explore the conditions to ensure that the transport of new cash currency runs smoothly and the replacement of unfit banknotes is seamlessly accepted - although these arrangements could also be done with commercial banks. In addition, clearing will at times need to go through that country's banking system, though not necessarily on the central bank's books.

The government and the central bank should prepare and disseminate a timetable for dollarization. There is no specific duration for the transition period. It can be as short as less

\footnotetext{
${ }^{13}$ When planning for the European Economic and Monetary Union (EMU), special criteria were selected to define and to monitor the convergence of the economies towards the EMU. Only European Union member countries whose economies fully met these so-called Maastricht convergence criteria during a certain period were eligible to join the EMU. The idea was that by this design, the EMU would consist only of economies that had proven their ability to conduct prudent policies in the monetary and fiscal areas. Accordingly, the Governing Council of the ECB has stated that: “...it should be made clear that any unilateral adoption of the single currency by means of "euroisation" would run counter to the underlying economic reasoning of EMU in the Treaty, which foresees the eventual adoption of the euro as the endpoint of a structured convergence process within a multilateral framework. Therefore, unilateral "euroisation" would not be a way to circumvent the stages foreseen by the Treaty for the adoption of the euro...."

${ }^{14}$ Any seigniorage sharing should be typically considered a gesture of goodwill from the country issuing the foreign currency and not an entitlement for the dollarizing country.
} 
than six months, like in Ecuador, where dollarization was adopted in the middle of a fullblown economic crisis. In general, the span for the implementation of official dollarization hinges on a number of factors, including the level of public support, the degree of macroeconomic stability, and institutional features such as the maturity of contracts in which dollar and domestic currency contracts coexist. The transition period should give sufficient time to explain economic agents about the road to dollarization, and how to operate under the new monetary regime. The timetable for dollarization should at least specify dates for: (i) when the rate of conversion will enter into effect and, if relevant, when the new currency will be officially the legal tender; (ii) when the central bank will stop conducting open market operations; (iii) when the central bank will start replacing the domestic currency with the new currency; (iv) the period of time in which both currencies will be allowed to circulate and the date when domestic coins and banknotes will be phased out from circulation; and (v) the dates in which financial system balance sheets will be converted into "dollars" and new accounting rules for the corporate sector will enter into effect.

A comprehensive communication strategy is at the heart of the implementation and success of official dollarization. Governments should respond and explain very basic questions that citizens may have, including why dollarization is adopted, how it will be implemented and, in particular, what is the timetable for its full implementation. Special emphasis should be given to the dissemination of: (i) the rate of conversion to re-denominate in dollars existing domestic currency prices, assets, liabilities, contracts, and financial transactions; (ii) a transitory period in which prices of goods and services will be announced in both currencies and the date in which the local currency will stop serving as mean of transaction; (iii) also important is to deploy a media campaign aimed at limiting "currency rounding," which tends to delay the achievement of price stability and, hence, elevates the level of prices. ${ }^{15}$ Specific information about the procedures for this transition should be provided to the financial system and other private enterprises in order to secure a smooth currency conversion in their balance sheets and contracts. The public sector should also receive clear guidelines as to how to migrate to the use of the new legal tender. In general, educating and informing the public is critical for the success of the currency conversion. To achieve this, all types of media (newspapers, radio, television, and internet) should be used, as well as posters and other informative material. Communication needs to reach economic agents and the general public at large.

\section{B. Operational Issues}

\section{The conversion rate}

As a country dollarizes, the most important operational issue to define is the rate at which the local currency is converted into the new legal tender. This may not be a problem if the country has a fixed exchange rate regime or if the economy is in steady state. However, in an

\footnotetext{
15 "Currency rounding" typically affects dollarizing countries with a high inflation background.
} 
environment of macroeconomic instability defining the exact exchange rate is not obvious. Two considerations are in order to guide this decision. First, choose the closest number to the market rate that makes it quick and easy for economic agents to make conversions between the two currencies. And, second, the conversion rate requires that key central bank liabilities are covered by the existing stock of net international reserves.

Another critical decision is to define a backing rule that allows covering specific central bank liabilities with international reserves. The backing rule is particularly relevant during the transition period, to assure the viability of the new monetary regime. This implies that, at the minimum, coins and banknotes of the local currency should be covered, but covering base money plus interest-bearing securities issued by the central bank is optimal. Failing to secure this backing rule would undermine the credibility and, eventually, the sustainability of the new monetary system. ${ }^{16}$ If a meaningful surplus of international reserves remains after applying the appropriate backing rule, a productive use of this surplus could be to create an emergency liquidity facility, which could be used beyond the transition period to cope with episodes of financial distress in absence of LOLR facilities. In dollarized countries that are highly dependent on the export of a single commodity, accumulating excess international reserves is warranted as a buffer to confront negative shocks. When it comes to new countries, international reserves are typically not available in meaningful amounts to provide a desirable backing of central bank liabilities. This would not necessarily prevent a successful effort to undertake official dollarization, because typically these countries keep utilizing the same currency that was used before, and, hence, there is no local currency to back. For instance, in Kosovo, no functioning central bank authority existed at the time of the de facto exit from Serbia, but parts of the Yugoslav payments bureau system still remained in Kosovo. In general, national central banks were built up over time, step by step, which had implications for a gradual phasing in of single national legal tender currencies.

To make explicit the viability of the new monetary regime and enhance the transition's credibility it is desirable to change the central bank's balance sheet presentation. In the new structure of the balance sheet, market participants should be able to monitor the availability of international reserves to back domestic currency in circulation as well as central bank securities. ${ }^{17}$ The modified presentation of the central bank balance sheet also gives information about any room for central bank's systemic liquidity management and, if possible, the likely limited provision of LOLR support. In case the central bank possesses quasi-fiscal liabilities, they should be absorbed by the government.

\footnotetext{
${ }^{16}$ Strictly speaking, beyond the transition period, there is no need to provide backing, except for bank reserves at the central bank and for coins when the country issues them locally.

${ }^{17}$ The alternative presentation of the Central Bank of Ecuador balance sheet is a good example to follow for countries dollarizing in a crisis environment (see details in the Appendix).
} 


\section{Interest rates' conversion}

When the country dollarizes under stable macroeconomic conditions, there is no need to change the parameters of contracts maturing after dollarization enters into effect, although negotiations may be allowed. Typically, interest rates decline following the official dollarization of the economy. In an environment of macroeconomic stability, the less disruptive way of converting domestic currency interest rates to dollar-denominated interest rates is to maintain the original terms and conditions of the contract and apply them at the conversion rate. Thus, at the expiration of the contract, all assets and liabilities, as well as interest rates in domestic currency are valued in dollars at the conversion rate. However, the converted into dollars' interest rates will probably still reflect the previous expected devaluation and country risk premiums. Even if these premiums are not large, the post dollarization converted interest rate will result in higher rates compared to those agreed in contracts during the post-dollarization period. To tackle this distortion, voluntary renegotiations may be allowed during an interim period. El Salvador followed this course of actions as financial institutions were authorized to convert gradually colones interest rates into dollar interest rates during the first three months after the law establishing official dollarization was approved.

When the country dollarizes under high inflation conditions, the government may set rules to convert domestic currency interest rates - agreed before dollarization was announced - into dollar rates. When inflation is running at very high levels, the domestic currency is typically in a free fall, and the country risk and interest rates in local currency are also inevitably high. In these circumstances, simply applying the conversion rate to transform interest rates into dollar-denominated rates will result in rates that are much higher-still reflecting devaluation and country risk premium - than the prevailing interest rates following the adoption of dollarization. Against this backdrop, and considering a possible asymmetry of powers of negotiations between the two parties in the contract, for example between the bank and a customer, a government intervention to "dollarize interest rates" may be warranted. This approach is disputed by Gruben and others (2003), who argue in favor of no government intervention. They claim that contracts always incorporate time-inconsistency contingencies, including dollarization. Moreover, they argue that governments are not well informed to interfere by changing the parameters of pre-dollarization contracts, and that introducing changes ex-post tend to create moral hazard in detriment of market discipline.

Converting domestic currency interest rates into dollar interest rates is difficult to implement in an environment of high inflation or hyperinflation. Typically, countries may approve legislation establishing the new level of interest rates for both domestic and dollardenominated contracts (the so-called desagio in Spanish). ${ }^{18}$ For instance, Ecuador implemented a desagio rule by adjusting interest rates in sucres and dollar-denominated

\footnotetext{
${ }^{18}$ The desagio has been applied in several previous episodes in which countries introduced a new domestic currency or when a currency board arrangement was established. The Plan Bonex in Argentina at the time of the introduction of the currency board in 1991 is a case in point.
} 
contracts to lower levels. The new rates were set and disclosed simultaneously when the adoption of the new legal tender was officially announced. ${ }^{19}$ There is no standard procedure to convert domestic currency interest rates into dollar interest rates. One alternative is to define reference rates for both the domestic currency and the new legal tender-as proposed in Schuler (2002) - and to convert interest rates from domestic currency to dollars by measuring them in terms of the reference rates. ${ }^{20} \mathrm{Of}$ course, defining the reference rate is critical; for the domestic currency, a central bank interest rate from open market operations is a valid pick; similarly, an equivalent central bank dollar rate can be chosen and, if it does not exist, a Libor or a Fed funds rate, plus an appropriate premium, may be used.

\section{Is there any room for conducting monetary operations and providing LOLR support?}

In a dollarized economy, the central bank loses its ability to conduct monetary operations. Given that the central bank is no longer in a position to issue its own national money, it should refrain from conducting monetary operations. Exceptionally, the central bank may redistribute liquidity among financial institutions - although it will necessarily be in limited amounts - during times of financial distress, provided it has international reserves to back these operations.

Bank reserves should be used primarily to support the operation of the payments system, but could also serve as an instrument for liquidity cushion. In Ecuador, bank reserves are used for payment systems purposes, whereas in El Salvador reserve requirements are an integral component of the financial safety net. In particular, in the latter country, bank reserves count in the calculations of liquidity requirements, but they are also part of a prudential liquidity measure determined by the Superintendency of Banks in absence of a central bank LOLR facility. ${ }^{21}$ To avoid taxing financial intermediaries, ideally, bank reserves should be remunerated. The interest rate paid on bank reserves should be consistent with the return the central bank obtains from investing these funds - which are effectively part of the international reserves.

\footnotetext{
${ }^{19}$ Interest rates were required to be adjusted for only one time, to 16.82 percent and to 9.35 percent for lending and deposit rates.

${ }^{20}$ For instance, the government may set reference rates of 100 percent and 10 percent for domestic currency and dollar denominated interest rates. Thus, applying these rates, a 120 percent local currency interest rate will be converted into a 12 percent rate in dollars.

${ }^{21}$ The initial unremunerated 20 percent reserve requirement was converted into a liquidity requirement of about 23 percent of deposits. These reserve requirements are comprised of three parts: (i) the first 25 percent is deposited and remunerated at the central bank or at a foreign bank, and can be automatically withdrawn; (ii) the second 25 percent is made of deposits at the central bank or a foreign institution, but could also be constituted by purchasing ad hoc government securities. Banks can have automatic access to these funds as well, but the central bank charges an interest rate in proportion to the amount withdrawn; (iii) the remaining 50 percent is constituted only by purchasing ad hoc government securities and banks cannot withdraw these funds without authorization of the Superintendents of Banks, who will impose a regularization plan to the troubled bank. Today, liquidity requirements are about 22 percent in effective terms, with an additional 3 percent that was introduced during the election cycle of 2004.
} 
Dollarizing countries should compensate - at least partially - the lack of an LOLR. Without the privilege of printing money, central banks in de jure dollarized countries are unable to fully exercise their function of LOLR. Yet, these countries may be hit by financial crises, which make the case for assisting problem banks with liquidity assistance. ${ }^{22}$ In practice, central banks in officially dollarized countries may only provide liquidity support if they hold a surplus of international reserves — which may not be large in a dollarized economy-like in countries with a currency board arrangement. An additional or complementary alternative is to build a contingent liquidity fund - constituted, for example, with foreign loans - to substitute central bank's role as LOLR. ${ }^{23}$ A similar arrangement consists in purchasing a private insurance policy with - foreign - private financial institutions, which is activated as needed or, in general, in case of crises. ${ }^{24}$ However, this arrangement may be very expensive and, hence, would entail large fiscal costs. Moreover, it would hardly work to tackle a systemic financial crisis, as observed in 2002 in Argentina.

With limited ability for central banks to act as LOLR, the focus is moved to the Ministries of Finance and to international multilateral institutions. The ability to deal with solvency problems in banks in the context of a financial crisis, the strength of the fiscal authority, and its willingness to allocate fiscal resources to a rescue effort, will be the key factors in determining the banks' chances of survival. ${ }^{25}$ Other than this, the recent financial crisis in the industrial world and its impact on the dollarized countries - which also have a large presence of international banking institutions dominating the financial system - showed that multilateral and regional financial institutions can play a crucial role in mitigating potential liquidity crunches. ${ }^{26}$

\section{Currency issues}

Procurement of the new currency. The central bank should have sufficient convertible currency available to procure the new currency. Banknotes (and coins) from the issuing country need to be purchased in sufficient quantities and in appropriate denominations (and

\footnotetext{
${ }^{22}$ However, dollarized countries may be less prone to suffer financial crises because the lack of an exchange rate eliminates the possibility that financial institutions have currency mismatches or are exposed to the credit risk associated with dollar loans provided to domestic currency-earning firms or individuals.

${ }^{23}$ Ecuador followed this path. The recently created liquidity fund will accumulate resources up to one time the amount of the system's regulatory capital.

${ }^{24}$ Argentina purchased this facility to serve the same purpose following the introduction of the currency board arrangement (see Baliño and Enoch, 1997).

${ }^{25}$ This aspect has been developed by Ize et al. (2005), where the focus is on partially dollarized economies. A distinction is there made between self insurance and external insurance, which is relevant for fully dollarized economies.

${ }^{26}$ For instance, El Salvador agreed with the Fund on an US\$800 million Fund program that would mainly serve as a liquidity buffer in the case that a liquidity event were to happen.
} 
subdenominations). Once dollarization is established and running, a valid question is who should be responsible of feeding the economy with dollar banknotes. While it is conceivable that the private sector could hold this responsibility, it is typically assigned to the central bank, on behalf of the government, given the strategic nature of importing and distributing banknotes to the economy on a timely basis.

"Dollarized" coins or new national coins. Some countries prefer to use national coins after adopting dollarization for various reasons: (i) to preserve a national symbol once the domestic currency has been eliminated and banknotes phased out from circulation; (ii) in case the U.S. dollar is the new legal tender, U.S. coins may be difficult to understand by people without knowledge in English because of the lack of numerals; (iii) also with respect to use of the U.S. dollar, the commonly used four U.S. coin denominations may be too few to fully meet the needs of low denominations; in particular, the lack of a 50 cent coin can be problematic; and (iv) transporting coins over long distances is very expensive measured by value. Ecuador and Timor-Leste are each using national coin series, which are fully convertible to U.S. dollars in their respective countries.

Period of dual currency circulation. Having to deal with two official currencies, leads to extra costs in the market place and other economic inefficiencies. Retail traders have to handle two sets of banknotes and coins and prices should be announced for some time in the two currencies according to the official conversion rate. Also, ATMs and automatic vendor machines need to be reprogrammed. To reduce the economic inefficiencies, the conversion period is normally set as short as possible taking into account the situation in the field to ensure an orderly exchange. ${ }^{27}$

Managerial and organizational systems for currency conversion. A currency conversion is a multi-pronged task that demands skill in a multitude of disciplines and at different levels to be successful. Depending on the institutional capacities, the central bank may or may not be in charge of managing the currency conversion. In Ecuador and El Salvador, the central bank led the currency conversion plan. However, in case the central bank lacks the appropriate skills, the best way of organizing and managing a currency conversion is as an off-line project, which avoids running it within the normal bureaucratic central bank organization.

Exchange points. To meet the time plan for the currency conversion, a suitable number of exchange points need to be identified. Existing banks and money changers should naturally be used, but also post offices; a number of temporary stationary exchange points should also be set up. Mobile units should be organized for the more distant parts of the country that lack much financial infrastructure. All exchange points need to be equipped with trained staff and security personnel, and with counting machines, security detectors, invalidation tools,

\footnotetext{
${ }^{27}$ In El Salvador, this period lasted six months following the approval of the law that officially established dollarization.
} 
accounting systems, and reporting systems, using normal telephones and faxes and/or mobile/satellite phones.

Distribution and storage of cash. The government and the central bank should prepare a logistics plan with a time table for key actions to be taken. During the conversion, the distribution and storage of new and old cash currency constitute a major challenge from a logistical point of view. The demands will vastly exceed the needs of a normal year as the exchange will encompass the whole outstanding stock of cash currency and not just the replacement of unfit banknotes together with the annual growth of cash currency. The transportation of currency will require extra resources. In addition, the storage needed for two types of cash currency will require additional temporary storage in containers, secured vaults, strong boxes, and safes. Many of these should be leased rather than purchased outright.

Invalidation and eventual destruction of national banknotes. To avoid fraud, national banknotes need to be invalidated at the time when they are exchanged for the new dollarized currency. Various invalidation techniques should be considered including mechanical shredding, use of ink and dye, and the use of manual and hydraulic punchers. The technique of invalidation used would vary with the conditions at the respective exchange points and should take place in a decentralized manner. All national banknotes should also eventually be destroyed after having been invalidated and counted. Techniques normally used include mechanical shredding and incinerating of banknotes. This is best done centrally rather than in a decentralized manner and should be integrated with the currency reporting system.

\section{Key COMPlementary StruCtural REForms}

A package of policy and structural reforms should be prepared, discussed, and approved to strengthen credibility and sustainability of dollarization. The shift to full dollarization raises important challenges and put a premium in intensifying structural reforms. A relevant question is whether these reforms should precede the adoption of official dollarization. While ideally they should be approved before official dollarization is enacted, it may not be possible should the country dollarize in the middle of an economic crisis and, in particular, if the country is going through hyperinflation. In this scenario, structural reforms should be approved in the short run and include, at least, reforms in the fiscal, financial, trade, and labor areas of the economy, as laid out below. Approving other reforms with the aim of boosting productivity and economic growth are also warranted-but their analysis is beyond the scope of this paper.

\section{A. Fiscal Reform}

With a central bank unable to provide credit to the government, a set of fiscal rules is desirable with the aim of preserving sound public finances in the long run. This policy entails building a tax base that provides a stable flow of revenues and expenses, consistent with a sustainable fiscal deficit. If government revenues depend critically on the export of one or two commodities, building stabilization funds is appropriate, thereby laying the groundwork 
for implementing a counter-cyclical fiscal policy. As an example, Ecuador, an oil-exporting economy, approved a fiscal responsibility law in 2002, which was aimed, primarily, at maintaining fiscal deficits in check, reducing the burden of the public debt, and using extra revenues from oil exports to establish a stabilization fund. ${ }^{28}$

Another key requirement relates to the importance of adequate and timely monitoring of expenditure commitments. Without this, many cash-based budgets in hard-peg countries have run up substantial arrears that have subsequently served to block the entire payment system. In this context, there may be a need for a better bankruptcy and debt resolution framework for dollarized economies.

Reducing or maintaining the public debt at sustainable levels should be an integral component of a prudent fiscal management as a way of preserving the country's access to capital markets. In addition, governments in official dollarized countries should develop a public debt capacity with the aim of facilitating treasury management. This is also very important because, as observed in many developing countries, governments may need financing to compensate shortages stemming from seasonal fluctuations in tax revenue, which no longer can be provided by central banks. ${ }^{29}$

Failing to preserve fiscal discipline and/or holding the burden of the debt at moderate levels would maintain country-risk indicators at high levels. Moreover, it would create uncertainty about the sustainability of public finances and, eventually, of dollarization. In this scenario, markets may fear that the government would at some point need to issue a local currency —or some imperfect substitute like the so-called "patacones" in Argentina before the currency board was abandoned in 2002 - to cope with a shortage of fiscal revenues and its inability to raise financing in debt markets to pay wages and, in general, government expenditures.

\section{B. Financial reform}

Banking crises can put at risk a dollarized regime and, hence, adopting a financial reform is critical to secure soundness and stability of the financial system. As a general rule, with limited or no LOLR facilities, there should be more stringent solvency and liquidity requirements. El Salvador has followed this approach as the authorities have increased the required risk-weighted capital-asset ratio to 12 percent - well above the 8 percent required in Basel I - and introduced in 2003 a special liquidity buffer equivalent to 9 percent of deposits. ${ }^{30}$ In addition, financial surveillance should be upgraded based upon a risk-based approach of bank supervision. Strengthening other elements of a financial safety net is also

\footnotetext{
${ }^{28}$ Overtime, however, the law has been changed extensively, which eventually has undermined the fiscal discipline initially envisaged.

${ }^{29}$ From a sample of 123 developing and emerging market countries, central banks are empowered to provide short-term credit — at less than one year maturity — in 60 countries, to cope with seasonal fluctuations in governments' revenues (see Jácome and others, 2010).

${ }^{30}$ This rate has changed over time as a prudential measure.
} 
critical, including prompt corrective actions, a deposit insurance mechanism and, in particular, effective and efficient bank resolution instruments coupled with clear exit rules. ${ }^{31}$ Ecuador recently approved a comprehensive reform along these lines. However, to get the most from this reform, having well-trained financial regulators is critical and, hence, capacity building should be part of the financial reform agenda.

The presence of foreign owned institutions in the financial system, as branches or subsidiaries, has been also part of the recipe to strengthen official dollarization. Conventional wisdom claims that foreign banks benefit financial systems in developing countries by reducing their vulnerabilities to financial crises, a potential threat to the subsistence of an officially dollarized regime. Foreign banks typically enjoy higher standards of corporate governance, which tend to be emulated by local banks. More important, they are perceived as better prepared to withstand episodes of financial stress and, hence, are less prone to bank runs and benefit from flight-to-quality, either because they have more alternatives to diversify risks because of their international links, or because they have more access to financing in case of a systemic liquidity crunch. In practice, except for Ecuador, other officially dollarized countries have a large penetration of foreign-owned banks. In particular, Panama is already an international financial center and in El Salvador foreign financial institutions recently became dominant players in the market place. Against this backdrop, the internationalization of financial markets has also been criticized in the wake of the recent world financial crisis because, precisely, international banks were the most adversely hit, thereby generating uncertainty about the stability of domestic financial systems.

Even when foreign owned institutions are largely present, there is still a need for robust prudential framework and regulation to address financial stability issues. The support of parent banks cannot be taken for granted, in particular, during periods of financial contagion. Moreover, close cooperation with home supervisors is always needed in order to keep under review the financial health of parent groups and their ability to support their local subsidiaries.

\section{Trade Reform}

Dollarizing countries should aim at reducing existing trade tariffs and distortions in order to expand the export base and, in general, to favor the sustainability in the new monetary regime. By definition, the appropriate functioning of an officially dollarized regime hinges on the availability of the foreign currency adopted as legal tender, which inevitably is the result of the inflows associated with exports of goods and services and capital inflows. In this connection, dollarized countries should embark on approving far-reaching trade reforms and should put in place a regulatory framework conducive to foster capital mobility inflows, as

\footnotetext{
${ }^{31}$ El Salvador increased the coverage of the existing deposit insurance; Panama and Ecuador do not have any.
} 
well as to encourage foreign direct investment. ${ }^{32}$ In the short run, lowering tariffs also benefit the convergence of domestic to world inflation.

In the long run, dollarized countries should also engage on trade negotiations with various countries in different regions of the world. A more open and integrated economy to world markets fosters exports activities and boosts economic growth. In addition, dollarization benefits from a stable flow of dollars to facilitate domestic transactions, which requires relying on a broad base of exports rather than relying excessively on a single or few commodities that are commonly subject to world price volatility. Also, multiple trade agreements might allow dollarized countries to untie its business cycle from that of the country issuing the foreign currency. Dollarized countries may also benefit from a diversified base of trade partners, because the effective real exchange rate becomes less dependent on the evolution of the foreign currency adopted as legal tender vis-à-vis other currencies.

\section{Labor Reform}

Since dollarized countries have no direct buffer to cope with the impact of adverse external shocks, they need to minimize nominal rigidities, in particular in the labor market. The competitiveness of tradable activities in officially dollarized countries is, to a great extent, linked to the performance of the foreign currency adopted as legal tender vis-à-vis other currencies. In addition, these countries are exposed to exogenous real shocks without any chance of using the exchange rate as a buffer like other countries. In these circumstances, officially dollarized countries have no other alternative but promoting and maintaining flexibility in the labor market to allow the economy to adjust to the new adverse environment. Thus, dollarized countries should make efforts to gain increased flexibility in the functioning of the labor market. Administrative wage increases should be handled with caution as they affect directly the competitiveness of tradable activities. Incentives for the creation of jobs and for enhancing labor mobility are also relevant.

In the short run, indexation clauses should be phased out to facilitate a rapid decline of inflation. While difficult in dollarizing countries running high and hyper inflation, the elimination of possible indexation clauses in wage contracts is crucial. De-indexation should be included in the legislation that establishes official dollarization and, if possible, should be introduced before dollarization is adopted to eliminate an element of inertial inflation, which might postpone convergence to world inflation.

\footnotetext{
${ }^{32}$ Although foreign direct investment is particularly attractive, excessive amounts into the non-tradable sector can have destabilizing effects.
} 


\section{REFERENCES}

Baliño, T. and C. Enoch, 1997, "Currency Board Arrangements: Issues and Experiences," Occasional Paper No. 151, (International Monetary Fund, Washington).

Berg, A. and E. Borensztein, 2000, "Full Dollarization: The Pros and Cons," Economic Issues No. 24, (International Monetary Fund, Washington).

Calvo, G., 2002, “On Dollarization,” Economics of Transition, Vol. 10 (2), pp. 393-403.

Corbo, V., 2001, "Is it Time for a Common Currency in the Americas?" Journal of Policy Modeling, Vol. 23, pp. 241-248.

Eichengreen, B., 2002, "When to Dollarize," Journal of Money, Credit and Banking, Vol. 34, No. 1, pp. 1-24.

Goldfajn, I. and G. Olivares, 2001, "Full Dollarization: The Case of Panama," Economia, Vol 1, No. 2 (spring), pp. 101-155.

Gruben, W., M. Wynne, and C. Zarazaga, 2003, "Implementation Guidelines for Dollarization and Monetary Unions,” in Levy-Yeyati, E. and F. Sturzenegger Eds. Dollarization: Debates and Policy Alternatives. MIT Press, Cambridge, Massachusetts.

Ize, A., M. Kiguel, and E. Levy-Yeyati, 2005, "Managing Systemic Liquidity Risk in Financially Dollarized Economies" IMF Working Paper No. 05/188.

Jácome, L.I., M. Matamoros-Indorf, M. Sharma, and S. Townsend, 2010, “Central Bank Credit to the Government: What Can We Learn from International Practices?" IMF Working Paper (forthcoming).

Levy Yeyati, E. and F. Sturzenegger, 2003, "Dollarization: A Primer," in Levy Yeyati, E. and F. Sturzenegger Eds. Dollarization: Debates and Policy Alternatives. MIT Press, Cambridge, Massachusetts.

Moreno-Villalaz, J.L., 1999, "Lessons from the Monetary Experience of Panama: A Dollar Economy with Financial Integration," Cato Journal, Vol. 18, No. 3 (Winter), pp. 421-439.

Panizza, U., E. Stein, and E. Talvi, 2003, "Measuring Costs and Benefits of Dollarization: An Application to Central American and Caribbean Countries," in Levy Yeyati, E. and F. Sturzenegger Eds. Dollarization: Debates and Policy Alternatives. MIT Press, Cambridge, Massachusetts.

Salvatore, D., 2001, "Which Countries in the Americas Should Dollarize?" Journal of Policy Modeling, Vol. 23, pp. 347-355.Schuler, K., 2002, "Fixing Argentina," Policy Analysis, No. 445, pp. 1-37. 


\section{ApPendix I. CASE STUdy: EcuAdor}

\section{Background}

Ecuador dollarized from one day to another amid a full-fledged financial crisis. As the banking system was falling apart and de facto dollarization had climbed to more than 50 percent of total bank deposits ( 38 percent a year before) the government announced on January 2000 the adoption of the U.S. dollar as legal tender. The government did not have time to lay out the institutional and operational basis nor to educate the population for the monetary reform. However, simply announcing the country's official dollarization improved market sentiments and stopped run on bank deposits.

\section{Institutional issues}

The legislation to implement dollarization was approved on March 13, 2000. The Economic Transformation Law (LTE) established a conversion rate of 25,000 sucres per dollar, the same rate already announced in January 10, 2000. Three key provisions of this law were: (i) the Central Bank of Ecuador (BCE) must not issue domestic currency any more; (ii) the BCE must exchange all sucres for dollars at the given exchange rate; and (iii) all economic agents must convert their accounting to dollars.

The new legislation laid out the BCE's primary functions. These functions included: (i) promoting macroeconomic stability of the country; (ii) managing the free disposable international reserves; (iii) preserving the functioning of the payments system; and (iv) being a fiscal agent. The LTE did not assign a new mandate to the BCE.

Communication played a critical role in the transition to the new monetary regime. The BCE designed a broad communication campaign entitled "knowing the dollar," which comprised 
three phases. Starting on April 2000, a massive educational effort was deployed to get the population acquainted with the new banknotes and coins. For selective audiences, a number of conferences and seminars were organized to explain the functioning of the new monetary regime and its expected benefits. The second stage began on September 2000 and addressed primarily the procedures to replace the old currency with the new legal tender. The major efforts were directed to rural areas. The final stage, implemented in February/March 2001 focused on the procedures required to finalize the currency exchange.

\section{Operational issues}

The rate of conversion was established in connection with the need of fully backing money base with central bank international reserves. In the wake of soaring inflation and currency depreciation, the conversion rate boosted exports, but the convergence of domestic to world inflation lasted more than four years.

The BCE changed the presentation of its balance sheet with aim of building credibility and enhancing transparency of the new monetary regime. The new presentation comprised four so-called systems: (i) in the "exchange system" the freely disposable international reserves (FDIR) appeared backing currency in circulation; (ii) in the "financial reserve system" additional FDIR backed bank reserves and central bank securities - in domestic currency; (iii) the "operations system" incorporated public sector and financial sector liabilities, including through other liabilities with international multilateral institutions and treasury operations, which were backed with any remaining FDIR; and (iv) the "system of other operations" included the remaining assets and liabilities plus BCE's equity and income statement's balances.

Central bank operations were narrowed down to focus exclusively on short-term liquidity management and to secure the appropriate functioning of the payments system. The BCE was allowed to issue exclusively short-term securities to mop-up liquidity surpluses. Reserve requirements were maintained as an instrument to secure a well-functioning payments system and, hence, the rate was gradually reduced from 11 to 4 percent for all bank deposits. Providing liquidity assistance to banks was legally proscribed.

A major task of dollarization was implementing currency conversion. As a first step, the BCE procured a family of coins with the same denomination than U.S. coins although with own physical characteristics. The local dollar coins began circulating by September 2000, which were exchanged at the BCE branches in the urban areas and at the National Development Bank for the rural areas. Currency conversion lasted one year. Dollarization also required revisiting the country's statistical data to express them in the new currency. 


\section{Appendix II. Case Study: El Salvador}

\section{Background}

El Salvador adopted the U.S. dollar as legal tender in 2001 in an environment of macroeconomic stability but after years of disappointing economic growth. Year-onyear inflation was on average below 4 percent during 19962000. Since 1993, the colon was pegged to the dollar. Simultaneously, fiscal and external disequilibrium was moderate (on average about 1.5 percent of GDP during 1993-2000) and financial dollarization was low. However, real interest rates were high and economic growth was on average about 3 percent during the second half of the 1990s. With the expectation of reducing real interest rates and fostering economic growth, the Salvadoran authorities officially dollarized at a conversion rate of 8.75 colones per U.S. dollar.

\section{Institutional issues}

El Salvador made domestic and international consultations before adopting dollarization. Given stable macroeconomic conditions, the government had time to build political support and define procedures handled primarily by the Reserve Central Bank (BCR). The Monetary Integration Law (MIL) was presented as a step to integrate the Salvadoran economy to world markets, a vehicle to accelerate economic growth. Dollarization was endorsed domestically and received support from multilateral institutions. Cooperation from the Federal Reserve was obtained exclusively for specific operational issues, such as the provision of U.S. dollars bills and coins, and training of the BCR staff on security procedures to avoid counterfeiting of the new currency.

The MIL laid out BCR powers and established flexible operational procedures for the transition to dollarization. Key elements of the new legislation included the following: (i) prohibit the BCR to extend credit to financial institutions and to print new currency notes beyond the existing inventory; (ii) retain BCR powers to issue bonds and to purchase, sell, 
and exchange portfolio and securities with financial institutions; (iii) restructure the LOLR framework, establishing a remunerated liquidity requirement (see below); and (iv) allowing the BCR to conduct repo operations with government resources in the event of a systemic liquidity shortfall. The MIL did not establish a deadline for conversion of colones into dollar coins and banknotes. No changes to the presentation of BCR's balance sheet were adopted.

The Salvadoran authorities deployed a vast communication strategy. Communication was critical to explain the benefits of dollarization in a country that benefit from a strong currency, quasi price stability, and low de facto dollarization. In addition, a public campaign was developed to facilitate trade and financial transactions in the new currency using a conversion rate that was not easy to handle for the vast majority of the population. Prices of goods and services were allowed to be expressed in both colones and U.S. dollars.

\section{Operational issues}

The conversion of colones into U.S. dollars lasted about two years. With no specific deadline to conclude the conversion of colones into dollars, the BCR followed a piecemeal approach distributing the new legal tender through the exchange points - primarily commercial banks. The Federal Reserve has been the main provider of dollars (banknotes and coins) directly to the BCR, and also takes care of the replacement of unfit banknotes.

The MIL established a 90-day period for the adjustment interest rates in pre-existing colones credits. To this end, financial institutions were required to refer to two criteria: (i) reduction in their financial costs; and (ii) prevailing interest rates for new dollar credits.

While the MIL retained BCR's powers to conduct a number of operations with financial stability purposes, it restricted BCR's capacity to lend to financial institutions. In particular, the BCR preserved its capacity to issue its own securities, although denominated in U.S. dollars. It was also entitled to purchase and swap these securities in the secondary market. In addition, the BCR could also swap assets with financial institutions in under the guidelines issued by its Directive Counsel, and conduct repo operations to preserve systemic liquidity. The MIL authorized the BCR to lend to the Deposit Guarantee Institute but prohibited lending to public and private financial institutions.

The MIL increased the financial system's liquidity requirements. It converted previous bank reserves into a remunerated liquidity requirement that banks can access to fund short-term liquidity shortfalls. Key rules for the use of these resources are the following: the first 25 percent is drawn free of interests; the second 25 percent is charged a market interest rate; the use of the remaining 50 percent requires authorization from the Superintendence of Banks and accepting a regularization plan designed together with the BCR. 


\section{Appendix III. Case Study: Kosovo}

\section{Background}

The official currency of Kosovo used to be the dinar, the currency of Socialist Federal Republic of Yugoslavia. However, for years DM were also widely use as money. As a result of a Regulation passed by the local UN administration in late 1999, the DM became de facto also legal tender in Kosovo with a preferred status compared to the new dinar. In the Mitrovica area situated in the northern part of Kosovo, which largely remained under Serbian control, the currency used in Serbia remained the primary legal tender. For the rest of Kosovo, the introduction of the DM represented a recognition of the reality in the field, as the new dinar was discredited financially (the experience of hyperinflation) and politically (the expulsion of Kosovar Albanians and the subsequent war). The choice of the DM was seen as a natural choice, although it was recognized that the physical DM in 1999 was formally merely one representation of the euro. Since the population was familiar with the DM, there was never any discussion on the need for introducing special national coins. During late 1999 and in 2000, dinar coins were used if no pfenning coins were available.

\section{Institutional issues}

In September 1999, the local UN administration passed a Regulation stating that all compulsory payment to the budget (taxes, customs duties, utility fees, and charges) where to be paid in DM. While the dinar remained formal legal tender, the UN Regulation stated that compulsory payments in that currency were subject to a surcharge of 10 percent in view of the manifest weakness and volatility of the new dinar.

The timing of the official euroization came early, only a few months after the local UN administration had received its mandate. The key reasons for this particular timing were the needs for a consistent UN budget for Kosovo for the financial year 2000. This created a number of institutional challenges such as reaching agreements with Bundesbank and the EU on the formal use of the DM and to have sufficient amounts of the right denominations of the currency transported into the capital. In this work, a resident IMF staff and later IMF advisory missions and technical assistance reports made critical contributions. 


\section{Operational issues}

The introduction of the DM was successful. The Kosovar population welcomed the change to DM, a currency that represented stability. Since many had hoarded German cash currency for years, they were prepared to use the DM once the political certainty was reestablished and the shift was smooth. In addition to the substantial amounts of money that became available that way, significant amounts of DM banknotes were imported into Kosovo by air by UNMIK. Initially, sufficient vault space was not available, leading to temporary improvisations such keeping cash currency in tents guarded by international military. The balance sheet of the newly established BPK — the nascent central banking authority — grew quickly.

In early 2002, the physical euro was successfully introduced, replacing the physical DM. The management of the dollarization process was from the beginning in the hands of the BPK supported by considerable technical assistance from the IMF and USAID. At the request of the local UN administration, the IMF and USAID provided a number of international staff to support the BPK. Some resident expatriate staff from the IMF and USAID took on key management positions in the BPK; other short-term experts were part of advisory missions or provided peripatetic advice in specialized areas. The ECB supported the euro conversion in Kosovo by cooperating fully with the BPK and made available planning material and sharing ideas on a massive outreach to the population. This was needed as the population were not only unfamiliar with the new banknotes and coins, but often expressed a preference for continue using the established and well-liked DM.

The legal and accounting side of the dollarization was handled by UN legal experts based in Kosovo, combined with assistance from the IMF. The dollarization program was also supported by a communications program using the media - television, radio, and newspapers. It was also supported by printed material prepared by the local UN administration and the BPK. As the population already was well-informed about the physical design and value of the DM, the challenges for the communication program were minimal.

Both the introductions of the DM and the euro took fundamentally place in an effective manner. The competence of local staff and the enthusiasm among the Kosovar population for the use of the new banknotes and coins were key factors that facilitated the conversions.

Among problems encountered, the key issues were staffing and logistics. Almost all bank offices had been destroyed or severely ransacked. So was the case of the branch office of the Yugoslav National Bank in Pristina, where also the vault for storing banknotes could not be used. Moreover, the contributions by local banks were nil as none of the old banks survived and few key staff were any longer available. With no banks and little functioning formal monetization, this meant that more of the work had to be done by outsiders - international experts and NATO troops - to practically implement the dollarization. 


\section{APpendix IV. CaSe Study: Montenegro}

\section{Background}

At the end of World War

I, the independent

Kingdom of Montenegro

joined what was later

known as Yugoslavia.

As a consequence, in

November 1918, the

national currency - the

perper (plural perpera) -

was substituted for the

(Yugoslav) dinar.

\section{Brief Chronology of Main Events}

Nov. 2, 1999: $\quad$ Montenegro decided to unilaterally establish a dual currency system with the DM as parallel legal tender to the Yugoslav dinar.

Nov. 13, 2000: $\quad$ Montenegro left the dinar monetary area, withdrawing the remaining dinars from circulation.

2000-01: $\quad$ Major importation of DM banknotes and coins.

Jan. 1, 2001: DM declared to be sole legal tender.

Mar. 15, 2001: The Central Bank of Montenegro started operating, replacing the National Bank of Yugoslavia.

Jan. 1, 2002: DMs started to be replaced by euro, which soon thereafter became sole legal tender.

2002: Massive replacement of DM banknotes and coins with euro cash currency.

May 21, 2006: Montenegro voted for independence from Serbia in a referendum.

\section{Institutional issues}

Montenegro had economic and political reasons for leaving the dinar and adopting the euro. The remarkable weakness of the Yugoslav currency and the hyperinflation generated in 1992-93 were key factors in undermining the confidence in the traditional legal tender. As a result, convertible currencies were de facto widely used for all the traditional functions of money. This was in part the result of significant remittances from Montenegrins living and working abroad. Moreover, over time, Montenegro was excluded from sharing seigniorage income with the National Bank of Yugoslavia, which ultimately stopped delivering banknotes to Montenegro.

The Montenegrin euroization was clearly a unilateral action, which initially was liberally tolerated by the key EU institutions due to the special political circumstances under which it took place. However, from the beginning, Bundesbank neither supported nor promoted the introduction of DMs in Montenegro. Bundesbank noted that there were no legal restrictions as to the use of DM in foreign countries. At the same time, Bundesbank stressed that it had no legal obligation to support countries that decide to use the DM as legal tender.

With the introduction of the physical euro and over time, EU's attitude hardened, emphasizing that only states that can fulfill the stability criteria for membership of the single currency set out in EU treaties are authorized to use the euro. EU and ECB spokesmen increasingly emphasized that unilateral euroization is not compatible with the treaties, which foresees adoption of the euro as the endpoint of a structured convergence process within a multilateral framework.

\section{Operational issues}

Like in Kosovo, DM banknotes and coins were already widely used as money prior to the euroization. The successful introduction of the DM in neighboring Kosovo also gave 
credibility to the move. The choice of the DM was not debated on economic grounds; no other currency was discussed as a potential alternative to the DM. However, the decision was highly divisive on political grounds.

In addition, the choice of timing for the dollarization was determined by political, rather than economic, considerations. It may be noted that the formal introduction of the DM as sole legal tender in Montenegro was taken in late 2000, five and a half years before eventual formal independence from Serbia was a reality.

With respect to the subdenomination of the new currency, there were no serious suggestions to introduce special national coins for normal use. Instead, originally the German pfenning was used and replaced in the course of 2002 by the euro's cent.

After dollarization, interest harmonization did not become very prominent in the banking sector. In Montenegro, the interest rates offered by commercial banks on loans and deposits have tended to vary considerably, reportedly as a consequence of different risk profiles for the financial institutions and their different customers. Also with respect to the yield of treasury bills, the interest rate dynamics in Montenegro has, by and large, not been in line with the general trends in the euro area. In part, this may reflect differences in inflation rates between Montenegro and key euro economies. 


\section{Appendix V. CASe Study: Timor-Leste}

\section{Institutional issues}

Based on a UNTAET

Regulation (= law)

issued in January 2000,

the U.S. dollar was made

official currency and

legal tender for all

public and private

transactions. At an early

stage, the Federal

Reserve had been

contacted about the idea

to which it had no

objections. As in the

case of Kosovo, the

concept of freedom of

contract gave parties to

any voluntary

transaction (or discharge

\section{Brief Chronology of Main Events}

Apr. 25, 1974: Military coup in Lisbon resulting in departure by the colonial administration.

Aug. 9, 1975: Internal coup led to a brief Timorese civil war.

Dec. 7, 1975: Indonesian military invaded.

Jul. 17, 1976: Formal integration as a province of Indonesia; Indonesian rupiah introduced.

Aug. 30, 1999: UN-sponsored popular referendum resulting in a majority for independence.

Nov. 27, 1999: A UN Transitional Administration for Timor-Leste (UNTAET) takes control.

Jan. 22, 2000: UNTAET Regulation No. 2000/7 on the establishment of a legal tender.

From 2000: $\quad$ U.S. banknotes and coins started being imported.

Jun. 8, 2001: Agreement with Bank Indonesia on the repatriation of rupiah cash currency.

Jul. 20, 2001: $\quad$ UNTAET Regulation No. 2001/14 on the official currency and legal tender.

May 20, 2002: Political independence achieved as UN transitional administration steps down.

During 2003: Importation of U.S. coins halted.

Nov. 10, 2003: Issue of new national centavo coins replacing U.S. coins.

of any debt) the right to denominate a payment obligation in any currency they wished to agree upon. However, for all compulsory payments to any public authority in the country (for example, taxes, customs duties, utility charges, and public fees), had to be made in the legal tender. On a transitory basis, UNTAET allowed that compulsory payments to the Timorese budget could be made also in rupiah, subject to an additional transaction fee of 20 percent.

The choice of these particular arrangements was the result of complex decisions. In early 2000, there was a general agreement that the time was not right for the introduction of a separate national currency. The economic and social conditions were difficult and the capacity to administer a new national currency simply did not exist. After intense discussions, the Timorese leadership agreed to the use of the U.S. dollar as national currency. The U.S. dollar's relative strength and stability were seen as an advantage to bring down inflation, which had been considerable with the rupiah regime. Additional advantages with adopting the U.S. dollar were that the major export product, coffee, was traded in that currency. Moreover, income from future sales of oil and natural gas, which were being explored, would also be traded in U.S. dollar. Like in Kosovo, a Banking and Payments Authority (BPA) was set up by the UN with IMF support to be in charge of cash currency matters, banking supervision, and otherwise to act in the absence of a central bank. An excellent institutional working relationship between the Fed and the BPA became an important factor in the practical handling of cash currency. 


\section{Operational issues}

For most of the period from 2000 until mid-2001, the Indonesian rupiah continued to be used as cash currency by most Timorese, while expatriate staff preferred to use the Australian dollar. During this time, the rupiah totally dominated the national cash payment system, while the U.S. dollar and other convertible currencies were favored as store of value.

In July 2001, after an agreement had been reached with the Indonesian central bank on the repatriation of the rupiah, UNTAET decided to make the U.S. dollar the official currency and sole de jure legal tender for all public and private transactions. In support of the single currency regime, a series of measures were introduced to strengthen the actual use of the U.S. dollar by the Timorese general public.

The promotion of the U.S. dollar comprised actions in a special dollarization program prepared by Fund experts and implemented from mid-2001 until March 2002. It focused mainly on three areas by: (i) insisting on the use of the legal tender for all public and private transactions; (ii) demanding that prices on all goods and service, as well as payment for all goods and service be denominated in the legal tender; and (iii) ensuring that all budgets, financial records, and accounts of all persons be maintained in the legal tender.

The promotion campaign was directed on educating the population on the features and use of the U.S. dollar. The program included seminars, press conferences, presentations, posters, and the use of electronic and printed media. The education campaign was extended to include market vendors, teachers, schools, civil servants, churches, transport operators, and business persons informing them of the provisions of the Regulation, providing coins in the districts, and assisting small businesses to convert prices to U.S. dollars.

Despite strong political support by the Timorese leadership, the initial dollarization effort largely failed. The public preferred to deal with the rupiah, a currency they knew and other concerns did not alter that preference. Also other currencies were frequently used, and the pricing of goods and services led to various nonmarket-oriented exchange rates. This was particularly confusing to the local population and became another reason for eventually supporting the full-dollarization campaign.

The use of coins became an important issue. When the use of dollar was widespread, another problem came to the forefront. An early finding was that the U.S. coins were not readily accepted by the general public, thereby complicating low-denomination payment transactions. To address this, a decision was made in 2003 to replace those coins with newly minted national coins in the five denominations. The new coins had clear numerals and motives connected to Timorese culture or well-known products. The coins quickly became a success and greatly facilitated the eventual actual phasing out of the rupiah. 